\title{
From farmers to livestock keepers: a typology of cattle production systems in south-western Burkina Faso
}

\author{
B. Zoma-Traoré ${ }^{1,2} \cdot$ A. Soudré ${ }^{3} \cdot$ S. Ouédraogo-Koné ${ }^{2} \cdot$ N. Khayatzadeh ${ }^{1} \cdot$ L. Probst $^{4}$ (D) J. Sölkner ${ }^{1} \cdot$ G. Mészáros ${ }^{1}$ (D)

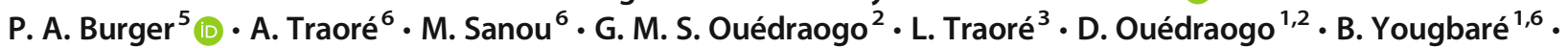 \\ M. Wurzinger ${ }^{1,4}$ iD
}

Received: 12 November 2019 / Accepted: 13 February 2020 / Published online: 3 March 2020

(C) The Author(s) 2020

\begin{abstract}
Cattle production is an essential livelihood strategy in south-western Burkina Faso. Although having a distinct cultural role and known to be resistant against African animal trypanosomosis, the Lobi taurine cattle breed is endangered due to its low market value. As the first step in preservation efforts, our study aimed to develop a typology of production systems at the farm level. We used a structured questionnaire and focus group discussions for collecting data on household characteristics, socioeconomic activities, livestock, and access to services. The sample comprised 169 households in three communities. The analytical strategy included factor analysis of mixed data and hierarchical clustering. We identified four distinct types of cattle production systems: (1) sedentary Lobi farms, (2) sedentary crossbreed farms, (3) semi-transhumant Fulani zebu farms, and (4) transhumant Fulani zebu farms. Significant factors in developing this typology were the farmers' ethnic group, crop diversity, cattle herd size, cattle herd composition, number of small ruminants, and livestock management strategies. Across all production systems, men were considered being primary decision-makers in cattle production, with women, herders, and children being responsible for specific tasks. All identified production systems are increasingly confronting disease pressure and scarcity of water and land. Future efforts in preservation and breeding will need to respond to these trends in the agroecosystem, integrate risk management measures, and resonate with the specific needs of the different household members involved in cattle rearing.
\end{abstract}

Keywords Farming system $\cdot$ Indigenous cattle $\cdot$ Burkina Faso $\cdot$ Lobi taurine cattle $\cdot$ Zebu cattle $\cdot$ Crossbreds

L. Probst

lorenz.probst@boku.ac.at

1 Division of Livestock Sciences, Department of Sustainable Agricultural Systems, University of Natural Resources and Life Sciences, Vienna, Austria

2 Institute of Rural Development, Nazi BONI University, Bobo-Dioulasso, Burkina Faso

3 Department of Life and Earth Sciences, Norbert ZONGO University of Koudougou, Koudougou, Burkina Faso

4 Institute for Development Research, Department of Sustainable Agricultural Systems, University of Natural Resources and Life Sciences, Vienna, Austria

5 Institute of Population Genetics, Department of Biomedical Sciences, University of Veterinary Medicine, Vienna, Austria

6 Department of Animal Production, Environmental and Agricultural Research Institute, Ouagadougou, Burkina Faso

\section{Introduction}

In Burkina Faso, the cattle production sector contributes between 36 and $40 \%$ to total agricultural added value and $26 \%$ to agricultural export value (FAO 2018; MAHRH 2011). Two species of cattle, Bos taurus and Bos indicus, are kept by farmers, agro-pastoralists, and pastoralists. Cattle are a valuable source of food (meat and milk products), provide services (transport and traction), function as a savings and insurance, and play a central role in the culture of different ethnic groups (Jahnke 1982; De la Rocque et al. 2001). The production strategies are based on local cattle breeds and have been described as extensive systems, including mixed crop-livestock, agro-pastoral, and pastoral systems (Kaboré 2012). Members of the Lobi ethnic group, practicing sedentary mixed croplivestock farming, have traditionally kept Lobi taurine cattle (Coulibaly 1989; Sicot 1993, Mopaté et al. 2014). Lobi taurine cattle are known to be resistant against African animal trypanosomosis (Sow et al. 2005; Dayo 2009; Soudré et al. 
2013). However, this breed is unpopular, mainly due to its small size and low market value. Consequently, livestock keepers frequently crossbreed Lobi taurines with larger Fulani zebu. This practice threatens the Lobi as a breed, which has, therefore, been classified as endangered (Sokouri et al. 2009). The Fulani zebu breed originates from the semiarid north of Burkina Faso and is traditionally reared by Fulani pastoralists, who move with their herds to the southern region of the country in search for pastureland and water. Previous studies described the cattle production systems in the region concerning the socioeconomic use of cattle (Coulibaly 1989), different technical management parameters (Sicot 1993), and the degree of integration with crop production (Tano et al. 2001). Mopaté et al. (2014) evaluated the castration of bulls of other breeds as a practice to ensure the conservation of the Lobi breed.

Given the farmers' preference for breeds with high market value, the productivity of Lobi taurine needs to be improved if the breed is to be preserved. Although Lobi cattle have low productivity in terms of meat and milk, they fulfill a fundamental role in Lobi society and are used in specific cultural events. Therefore, proper management of the breed is relevant to maintain it as an integral part of cultural identity (FAO 2015).

To achieve this, community-based breeding programs (CBBPs), an approach to involve livestock keepers in systematic breeding and management efforts, could be a viable option. CBBPs have been successfully implemented to improve mainly small ruminant production - e.g., of Djallonké sheep in Cote d'Ivoire (Yapi-Gnoaré 2000), Deccani sheep in India (Nimbkar et al. 2002), dairy goats in Mexico (Wurzinger et al. 2013), sheep in Ethiopia (Duguma et al. 2011; Haile et al. 2013; Mirkena et al. 2012), and goats in Iran and Kenya (Mueller 2013; Ojango et al. 2010).

For implementing CBBPs, a thorough understanding of current production systems and farmers' needs is essential (Sölkner et al. 1998; Kruska et al. 2003; Dossa et al. 2009; Scherf and Tixier-Boichard 2009; FAO 2010; Wurzinger et al. 2011; Robinson et al. 2014). As a first step in preservation efforts, our study aimed, therefore, to develop a typology of production systems at the farm level in south-western Burkina Faso.

\section{Materials and methods}

\section{Study area and sites}

The study was carried out in the south-western region of Burkina Faso, located at latitude of $10^{\circ} 19^{\circ} 00^{\prime} \mathrm{N}$ and longitude of $3^{\circ} 10^{\circ} 00^{\prime} \mathrm{W}$, covering about $16,533 \mathrm{~km}^{2}$ (MEF/DREP 2014). The region lies in the mountainous South Sudanese phytogeographical zone, with a rainy season from April to October and a dry season from November to March. The annual precipitation totals between 900 and $1200 \mathrm{~mm}$, with temperatures ranging from 21 to $32{ }^{\circ} \mathrm{C}$ (ANAM 2017). Forest and savanna dominate the vegetation (MAHRH/GTZ 2014). About 850,000 people live in the region, and the population growth rate is about $4.5 \%$, including a positive net migration rate of $2 \%$ (INSD 2018). The population is composed of different ethnic groups, which are considered being local (Lobi, Dagara, Birifo, Djan, and Pogouli) or immigrants from other regions of Burkina Faso (Mossi, Fulani, and Bobo).

For the research, we focused on the administrative units of Bouroum-Bouroum, Kampti, and Loropeni in the Poni province. The province is typical for the region in terms of pastoral and agricultural system dynamics, as it attracts an influx of migrants from areas with less rainfall and higher chances of drought. In the province, all three types of cattle which are common in Burkina Faso are kept: zebu, taurine, and crossbreds between them.

\section{Data collection}

We collected data using a structured questionnaire and focus group discussions (FGD) from May to September 2018. The sampling population included farmers and pastoralists of three municipalities. For lack of a registry of agricultural producers in the area, we could not apply probability sampling and resorted to a purposive sampling strategy. We collaborated with local extension workers and farmer leaders to identify households that represent the diversity of production systems in the region, and 169 heads of household (all male) agreed to participate. We tested the questionnaire with 15 farmers as a means to improve the final design of the research instrument. We tested the questionnaire with 15 farmers as a means to improve the final design of the research instrument.

The questionnaire comprised household characteristics, socioeconomic activities, livestock data, and access to services such as input supply, credit, and veterinary services. Farmers were asked to score production and management constraints by applying a scale of 1 to 4 ( $1=$ not important/least serious and $4=$ very important/most serious).

In a second step, we held separate focus group discussions with Lobi and Fulani respondents to triangulate and illustrate the survey results with qualitative data. Twenty Fulani men and 17 Fulani women attended the first focus group discussion, and 35 Lobi men and 25 Lobi women attended the second focus group discussion. To reduce possible gender effects on the discussion dynamics, men and women were invited to work on the same questions in separate groups. For validation and further discussion, each group then shared the results in a plenary setting. With the participants' consent, we audio recorded the discussions and documented visual exercises with a digital camera.

All activities were carried out in the local languages preferred by respondents (Dioula, Moore, and Lobiri). 


\section{Data analysis}

The qualitative data collected in the FGDs were compiled as written notes for triangulation and interpretation of the survey data.

The survey data were entered into Excel and analyzed using R (v 3.6.1). To explore the data, we used descriptive statistical parameters (mean, standard deviation, minimum and maximum).

To develop a typology of production systems, we applied hierarchical clustering on principal components (HCPC). We reduced the dataset dimensions into non-correlated dimensions, explaining much of the variance of the original dataset, using factor analysis of mixed data (FAMD). FAMD allows conducting a principal component analysis on datasets containing both categorical and continuous variables. Subsequently, we performed a hierarchical cluster analysis (HCA). As input to the FAMD, we used sixteen variables (4 categorical and 12 continuous) (Table 1). We interpreted the scree plot (Fig. 1) to determine the appropriate number of dimensions to be retained for clustering (Joliffe 1986). The hierarchical clustering was performed using Ward's method, and the gap statistic (Tibshirani et al. 2001) was employed to infer the most appropriate number of clusters. This is done by bootstrap iterations until convergence is reached. The analysis and visualization were performed using the FactoMineR and factoextra packages in R. The identified clusters were compared using $x^{2}$ tests for categorical variables and the nonparametric Kruskal-Wallis test followed by Wilcoxon-tests with Bonferroni-Holm correction for pairwise comparison of continuous variables. Statistical differences were considered significant at $p<0.05$. The production constraints were ranked using rank means.

\section{Results}

\section{Typology of production systems}

The characteristics of the sample are summarized in Table 1.

We included sixteen variables (Table 1) in the FAMD and retained four principal components based on the scree plot (Fig. 1): the scree curve is steep, and the "elbow" is located at four dimensions (cutoff point). These four dimensions describe $62.15 \%$ of the total variance (Table 2).

The cluster analysis yielded four distinct clusters, which we subsequently compared to develop the typology of production systems. For each cluster, we chose a name that represents its most characteristic features (Table 3).

\begin{tabular}{|c|c|c|c|c|c|}
\hline Categorical variables & Category & & & $n$ & $\%$ \\
\hline \multirow[t]{2}{*}{ Ethnic group } & Fulani & & & 58 & 34.32 \\
\hline & Lobi & & & 111 & 65.68 \\
\hline \multirow[t]{2}{*}{ Hiring labor } & Yes & & & 91 & 53.85 \\
\hline & No & & & 78 & 46.15 \\
\hline \multirow[t]{2}{*}{ Cattle purchase } & During the past 12 months & & & 50 & 29.59 \\
\hline & Not during the past 12 months & & & 119 & 70.41 \\
\hline \multirow[t]{2}{*}{ Cattle feed supplement } & Used during dry season & & & 165 & 97.63 \\
\hline & Not used & & & 4 & 2.37 \\
\hline Continuous variables & Description & Mean & $S D$ & Min & $\operatorname{Max}$ \\
\hline Total farmland area & Farm size (ha) & 4.7 & 3.84 & 0 & 20 \\
\hline Total cashew area & Cashew farm size (ha) & 2.2 & 4.45 & 0 & 30 \\
\hline Crop diversity & Number of vegetable varieties grown & 3.3 & 1.50 & 0 & 8 \\
\hline Cattle (excl. oxen) & Number of cattle (excl. oxen) in the herd & 53.01 & 67.47 & 0 & 400 \\
\hline Oxen & Number of oxen in the herd & 2.47 & 2.01 & 0 & 10 \\
\hline Zebu & Number of zebu in the herd (head of cattle) & 32.19 & 63.67 & 0 & 404 \\
\hline Crossbred & Number of crossbred in the herd & 14.69 & 31.74 & 0 & 202 \\
\hline Taurine & Number of taurine in the herd & 8.6 & 10.96 & 0 & 64 \\
\hline Sheep & Number of sheep & 14.91 & 17.61 & 0 & 110 \\
\hline Goat & Number of goats & 12.28 & 11.66 & 0 & 50 \\
\hline Vaccinations per year & Number of vaccinations per year & 2.39 & 1.36 & 0 & 5 \\
\hline Cattle sold & Number of cattle sold during past 12 months & 4.87 & 7.46 & 0 & 47 \\
\hline
\end{tabular}




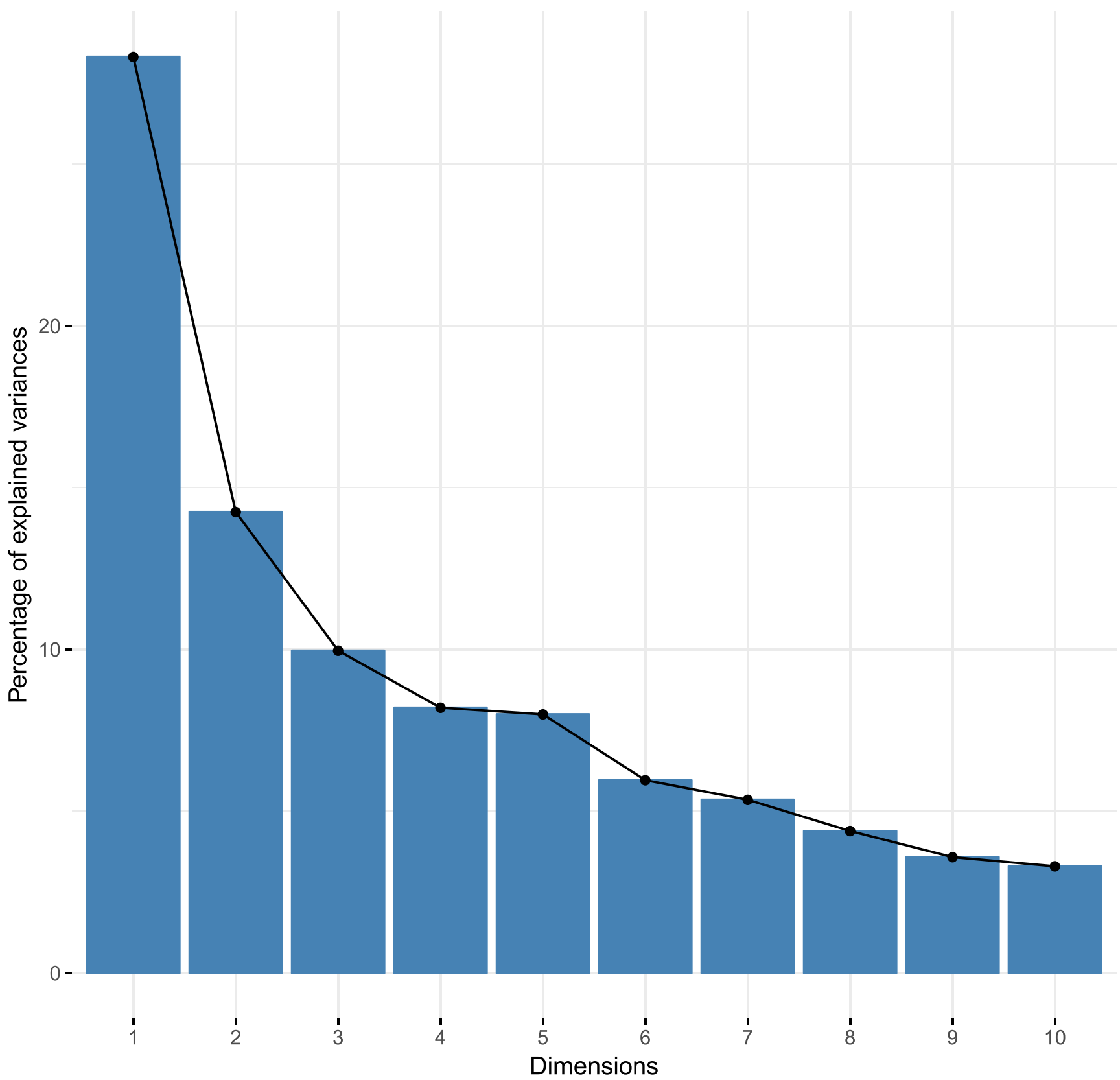

Fig. 1 Scree plot illustrating the percentage of variation explained by dimension

The first type of production system - which we refer to as "sedentary Lobi taurine farms"- comprised $40.24 \%$ of the interviewees, all of whom were Lobi. This system was characterized by a low number of cattle (an average of 20.7 heads) with the vast majority being taurine cattle (83.57\%) for draught, saving and insurance, and social functions such as funerals, sacrifices, and dowry (Table 3). In this system, the cattle were herded by children in the rainy season, and free grazing was practiced after the crop harvest and during the dry season. The frequency of treatment against trypanosomosis was low due to natural resistance in taurine cattle. Farmers rarely sold their cattle, and when they did, it was only in case of urgent financial needs.
The second system - which we refer to as "sedentary crossbreed farms"- -was also focused on crop production, but cattle played a more central role as a mechanism for savings and insurance, as draught animals, and as providers of manure for crop production. Farmers pursuing this strategy raised at least two types of cattle, with the majority being crossbred (64.12\%), mainly used as draught animals, according to farmers (FGD). Crossbred animals were also considered more resistant to trypanosomosis than zebu and more profitable than taurine. The average number of cattle per household was about 52 heads (Table 3). The farmers relied on paid workers for herding the animals throughout the year. Similar to the "sedentary Lobi taurine farms" strategy, cattle were not sold regularly (Fig. 2). 
Table 2 Results of FAMD: factor loadings

\begin{tabular}{|c|c|c|c|c|}
\hline Name of Variables & $\begin{array}{l}\text { Components } \\
1\end{array}$ & 2 & 3 & 4 \\
\hline Hiring labor & -0.664 & -0.188 & 0.196 & 0.361 \\
\hline Ethnic group & 0.877 & -0.192 & 0.212 & -0.152 \\
\hline Cattle purchase & 0.436 & -0.347 & 0.036 & 0.031 \\
\hline Cattle feed supplement & -0.143 & -0.330 & -0.042 & 0.491 \\
\hline Total farmland area & -0.566 & 0.562 & -0.011 & 0.044 \\
\hline Total cashew area & -0.287 & 0.369 & -0.467 & -0.107 \\
\hline Crop diversity & -0.745 & 0.306 & -0.199 & 0.144 \\
\hline Cattle (excl. oxen) & 0.757 & 0.411 & -0.100 & 0.422 \\
\hline Oxen & -0.210 & 0.711 & 0.073 & -0.033 \\
\hline Zebu & 0.775 & 0.211 & -0.038 & 0.462 \\
\hline Crossbred & 0.236 & 0.446 & -0.232 & -0.133 \\
\hline Taurine & -0.569 & 0.145 & 0.293 & 0.291 \\
\hline Sheep & 0.162 & 0.224 & 0.734 & -0.153 \\
\hline Goat & -0.048 & 0.379 & 0.694 & -0.044 \\
\hline Vaccinations per year & 0.628 & 0.322 & -0.150 & -0.379 \\
\hline Cattle sold & 0.751 & 0.308 & -0.020 & 0.406 \\
\hline Eigenvalues & 4.96 & 2.18 & 1.54 & 1.26 \\
\hline Variance $(\%)$ & 31.03 & 13.62 & 9.64 & 7.86 \\
\hline Cumulative variance $(\%)$ & 31.03 & 44.65 & 54.29 & 62.15 \\
\hline
\end{tabular}

N.B. Bold numbers refer to loadings higher than 0.5

In the third production system - which we refer to as "semitranshumant Fulani zebu farms"-interviewees focused on milk and meat production for the market, with limited crop production of sorghum or millet for home consumption. Contrary to the two first production systems, the vast majority of producers were Fulani (97.78\%). Considering the crucial role of livestock for their livelihoods and also the higher number of zebu in this production system $(75.12 \%)$, the respondents indicated higher costs for fencing, feed, and veterinary services. Furthermore, this system, with an average of about six cattle sold a year, was more cattle market oriented than clusters 1 and 2. The average number of cattle was 60.3 heads per herd, and producers were moving within a local territory during the dry season.

The fourth production system-which we refer to as "transhumant Fulani zebu farms"- resembles cluster three in many features, including the ethnic group, the high number of zebu cattle, and the management system with a high amount of hired labor. The higher average number of 217.7 heads per head conferred the owner a high place in the society and security of vicissitudes of life. However, the high number of cattle forced them to migrate beyond the national boundaries during the dry season regularly. Moreover, they kept their cattle far from settlements during the rainy season to prevent herds from causing damage to farmers' fields. This system was the most cattle market oriented, with an average of 23.5 heads sold a year.
Across all four systems, cattle management was a family task, and men were widely considered having the primary responsibility for the cattle, supported by women and children. To different degrees, all family members were involved in feeding, watering, vaccination, and construction and cleaning of feedlots. Decisions regarding the purchase of cattle, feed supplements, and veterinary services were mostly the preserve of men. The men were also responsible for preventing animal theft, searching for lost animals, and for solving conflicts with other livestock keepers and farmers. Women were mostly in charge of calves, sick animals, small ruminants, watering animals, and milking. Breeding was not mentioned as a relevant task (FGD results).

The systems differed, however, regarding the distribution of labor. In "sedentary Lobi taurine farms," family members were the main source of labor. In the "sedentary crossbreed farms" cluster, Fulani laborers managed the cattle. Farmers hired the laborers and covered the costs related to animal treatment and feeding. In the FGDs, women participants of these groups emphasized that they do not consider the distribution of labor and income fair - their contribution to livestock production, including the provision of water in the dry season, was an addition to sustaining the family, while the control over cattle revenues remained with the men.

In the "semi-transhumant Fulani zebu farms" system, cattle management was again a shared family task: herding was carried out by the owners and their children - particularly in Fulani households, in which all boys were herding after school. In this system, women were responsible for milking and milk processing as well as selling milk products. They also produced soap and butter for domestic use and sale. In contrast to women from sedentary farms, women participants in the FGDs of this group were not concerned by the question of sharing income fairly. However, while their husbands were satisfied with the division of labor, women in this group called for more support and appreciation by men.

In cluster four, "transhumant Fulani zebu farms," the respondents were not directly involved in cattle management as cattle were kept far from the homestead. Laborers managed the cattle, and the owners visited the herds for follow-up only. In this system, women were not regularly involved in cattle production.

\section{Constraints on cattle production}

We summarize the identified constraints on cattle production in Table 4. In all production systems, farmers considered the lack of drinking water for animals, the lack of feed (pasture), and the pressure of diseases and parasites being the primary challenges. Further constraints were the high costs of veterinary drugs and the high mortality of young animals. In general, the number of constraints mentioned increased with the herd size of farmers. The individual perceptions were corroborated 
Table 3 Characteristics of different production system in south-western Burkina Faso

\begin{tabular}{|c|c|c|c|c|}
\hline & Cluster & & & \\
\hline & 1 & 2 & 3 & 4 \\
\hline & $\begin{array}{l}\text { Sedentary Lobi } \\
\quad \text { taurine } n=68\end{array}$ & $\begin{array}{l}\text { Sedentary crossbreed } \\
\quad n=42\end{array}$ & $\begin{array}{l}\text { Semi-transhumant } \\
\quad \text { Fulani zebu } n=45\end{array}$ & $\begin{array}{l}\text { Transhumant Fulani } \\
\text { zebu } n=14\end{array}$ \\
\hline \multicolumn{5}{|l|}{ Ethnic group } \\
\hline Fulani (persons) & 0 & 0 & 44 & 14 \\
\hline Lobi (persons) & 68 & 42 & 1 & 0 \\
\hline \multicolumn{5}{|l|}{ Household attributes } \\
\hline Household size (persons: mean/SD) & $14.8 \mathrm{a} / 8.34$ & $16.2^{\mathrm{a} / 7.82}$ & $10.8^{\mathrm{b}} / 4.98$ & $16^{\mathrm{a}} / 6.09$ \\
\hline Age of household head (years: mean/SD) & $55.4^{\mathrm{a}} / 11.33$ & $51.4^{\mathrm{ab}} / 11.43$ & $46.2^{\mathrm{b}} / 13.55$ & $49.9^{\mathrm{ab}} / 8.43$ \\
\hline \multicolumn{5}{|l|}{ Education of household head } \\
\hline Literate $(\%)$ & 10.29 & 35.71 & 11.11 & 7.14 \\
\hline Illiterate $(\%)$ & 89.71 & 64.29 & 88.89 & 92.86 \\
\hline \multicolumn{5}{|l|}{ Main purpose of cattle production } \\
\hline Cattle for saving/insurance (\%) & 10.30 & 47.62 & 0.89 & 14.29 \\
\hline Cattle as draught animal (\%) & 58.82 & 38.09 & 00 & 00 \\
\hline Cattle for sacrifices, dowry and others social events (\%) & 30.88 & 14.29 & 00 & 00 \\
\hline Cattle as main source of livelihood (\%) & 0 & 0 & 91.11 & 85.71 \\
\hline \multicolumn{5}{|l|}{ Livestock ownership and management } \\
\hline Cattle excl. Oxen (number of animals: mean/SD) & $18.1^{\mathrm{a} / 12.96}$ & $49.2^{\mathrm{b}} / 55.10$ & $58.8^{\mathrm{c}} / 36.89$ & $215.4^{\mathrm{d}} / 93.94$ \\
\hline Oxen (number of animals: mean/SD) & $2.6^{\mathrm{a}} / 2.13$ & $3.2^{\mathrm{a} / 2.41}$ & $1.5^{\mathrm{b}} / 1.12$ & $2.3^{\mathrm{ab}} / 1.07$ \\
\hline Total cattle (number of animals: mean/SD) & $20.7^{\mathrm{a}} / 13.54$ & $52.4^{\mathrm{b}} / 55.51$ & $60.3^{\mathrm{b}} / 37.24$ & $217.7^{\mathrm{c}} / 94.23$ \\
\hline Taurine (number of animals: mean/SD) & $17.3^{\mathrm{a}} / 11.90$ & $5.3^{\mathrm{b}} / 4.79$ & $0.9^{\mathrm{c}} / 3.27$ & $0.9^{\mathrm{c}} / 2.67$ \\
\hline Crossbred (number of animals: mean/SD) & $1.1^{\mathrm{a} / 2.51}$ & $33.6^{\mathrm{b}} / 48.79$ & $14.1^{\mathrm{c}} / 21.15$ & $26.1^{\mathrm{bc} / 41.18}$ \\
\hline Zebu (number of animals: mean/SD) & $2.3^{\mathrm{a}} / 4.03$ & $13.6^{\mathrm{b}} / 25.49$ & $45.3^{\mathrm{c}} / 40.49$ & $190.7^{\mathrm{d}} / 106.15$ \\
\hline \multicolumn{5}{|l|}{ Hired labor (\%) } \\
\hline Yes & $8.82^{\mathrm{a}}$ & $73.81^{\mathrm{b}}$ & $91.11^{\mathrm{c}}$ & $92.86^{\mathrm{bc}}$ \\
\hline No & 91.18 & 26.19 & 8.89 & 7.14 \\
\hline \multicolumn{5}{|l|}{ Cattle bought (\%) } \\
\hline Yes & $39.71^{\mathrm{a}}$ & $50^{\mathrm{a}}$ & $4.44^{\mathrm{b}}$ & $00^{\mathrm{b}}$ \\
\hline No & 60.29 & 50 & 95.56 & 100 \\
\hline Cattle sold (number of animals: mean/SD) & $1.3 \% / 1.4$ & $3.1^{\mathrm{b}} / 4.26$ & $6.1^{\mathrm{c}} / 4.91$ & $23.5^{\mathrm{d}} / 10.75$ \\
\hline \multicolumn{5}{|l|}{ Small ruminants } \\
\hline Sheep (number of animals: mean/SD) & $14.6^{\mathrm{a}} / 15.65$ & $6.9^{\mathrm{b}} / 9.21$ & $23.2^{\mathrm{a}} / 23.67$ & $13.6^{\mathrm{ab} / 11.63}$ \\
\hline Goat (number of animals: mean/SD) & $14.3^{\mathrm{a} / 11.94}$ & $8.7^{\mathrm{b}} / 9.52$ & $12.9^{\mathrm{ab}} / 11.88$ & $10.9^{\mathrm{ab}} / 13.83$ \\
\hline \multicolumn{5}{|l|}{ Agriculture } \\
\hline Crop farm size (hectares: mean/SD) & $6.3^{\mathrm{a} / 3.82}$ & $6.4^{\mathrm{a}} / 3.84$ & $1.6^{\mathrm{b}} / 1.25$ & $2^{\mathrm{b}} / 1.21$ \\
\hline Cashew cropping area (hectares: mean/SD) & $1.6^{\mathrm{a} / 2.13}$ & $6.3^{\mathrm{b}} / 6.99$ & $0.02^{\mathrm{c}} / 0.15$ & $0.07^{\mathrm{c}} / 0.27$ \\
\hline
\end{tabular}

${ }^{a b c}$ Means within rows that do not have a common superscript are significantly different at $p<0.05$ level

in the FGDs, and the participants across all systems considered migration into the area, transhumance, and the growing population as main trends affecting agricultural production. Although water scarcity was frequently mentioned, this was attributed to the high demand rather than a changing climate. Owners of "sedentary Lobi taurine farms" and "sedentary crossbreed farms" suggested that they needed more knowledge to improve cattle management. Owners of "semi-transhumant Fulani zebu farms" and "transhumant Fulani zebu farms" found problems of damage on farmland and conflicts with farmers most constraining on their cattle production.

The study participants discussed adaptation pathways in the FGDs. Respondents whose primary occupation was livestock production considered a reduction of livestock density and an improved social organization of different agricultural activities in the region being the main adaptation pathways. Sedentary farmers, however, proposed to focus on the intensification of agricultural production. 


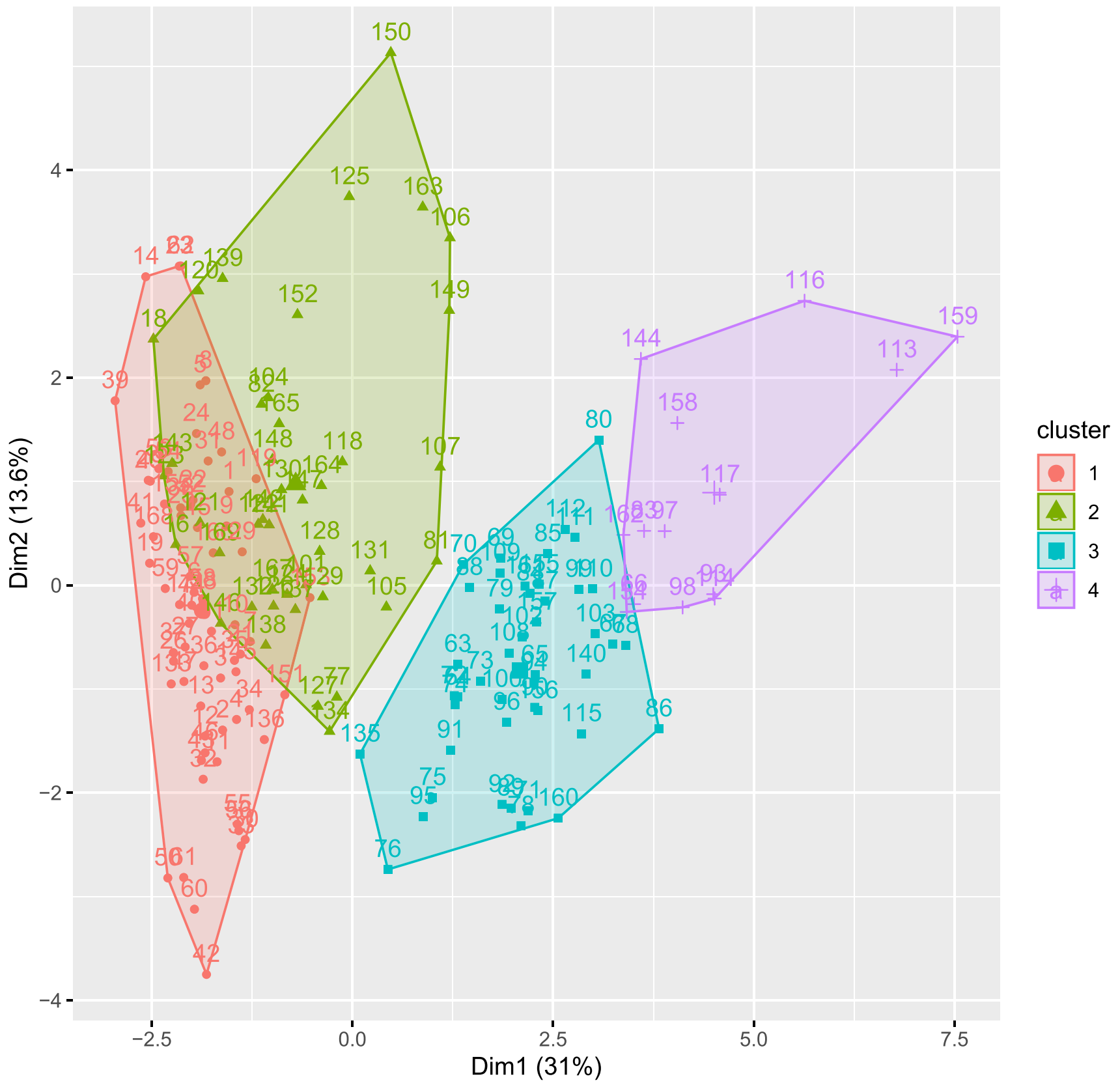

Fig. 2 Cluster plot showing the four clusters (outcome of the hierarchical cluster analysis) in the FAMD component 1 and 2 plane

\section{Discussion}

\section{Household characteristics}

Age and literacy of household heads across the different production systems found by this study are in accordance with earlier work in the region (Soro et al. 2015; Mopaté et al. 2014). Any effort to fostering breeding programs in the region will need to take into account that the farming population is aging and mostly illiterate. Integrating their knowledge and experiences will be crucial to initiate any learning process for change. Earlier research has documented that literacy is a crucial factor in agricultural innovation (Adeleye et al. 2016).

Also, effective breeding efforts will have to resonate with the preferences and needs of a diversity of persons who have a role in cattle rearing: men as official decision-makers, but also women regarding milk production and processing, as well as hired herders.

\section{Crop production}

An increasing number of production risks confront smallholder agriculture in Sub-Saharan Africa, and agroecosystem 
Table 4 Primary constraints in cattle production in south-western Burkina Faso (mean scores)

\begin{tabular}{lllll}
\hline Constraint & $\begin{array}{l}\text { Sedentary Lobi } \\
\text { taurine farms }\end{array}$ & $\begin{array}{l}\text { Sedentary } \\
\text { crossbreed farms }\end{array}$ & $\begin{array}{l}\text { Semi-transhumant } \\
\text { Fulani zebu farms }\end{array}$ & $\begin{array}{l}\text { Transhumant Fulani } \\
\text { zebu farms }\end{array}$ \\
\hline Drinking water & 3.33 & 3.42 & 3.72 & 3.89 \\
Lack of pasture & 2.9 & 3.24 & 3.58 & 3.75 \\
Diseases and parasites & 2.46 & 3.41 & 3.52 & 3.72 \\
Damage on farmland & 1.77 & 2.56 & 2.02 & 3.56 \\
Conflict between farmers and breeders & 1.3 & 2.43 & 2.84 & 3.43 \\
Young animal mortality & 2.05 & 2.16 & 2.38 & 3.21 \\
Feed shortage & 1.86 & 1.97 & 2.02 & 2.41 \\
Theft or predators & 2.37 & 2.13 & 2.38 & 2.55 \\
High veterinary costs & 1.97 & 2.27 & 1.94 & 2.5 \\
Insufficient technical knowledge & 2.34 & 2.22 & 2.32 & 1.45 \\
High input costs & 1.79 & 1.91 & 2.04 & 2.96 \\
Marketing problems & 1.42 & 1.88 & 2.04 & 2.27 \\
Housing problems & 2.06 & 2.03 & 1.98 & 2.07 \\
Access to credits & 1.38 & 2.16 & 1.8 & 1.5 \\
Access to extension service & 1.57 & 1.73 & & 1.67 \\
\hline
\end{tabular}

diversification has been identified as a main buffer strategy (Altieri et al. 2015; Hänke and Barkmann 2017; Gbegbelegbe et al. 2018). In our study, farm size, market prices, and climate change were drivers for diversifying production systemswhich is in agreement with earlier research in the region showing that farmers who own larger plots diversify into profitable cash crops (Ouédraogo et al. 2010; Audouin 2014). Livestock keepers, who are often landless, tend to rent small parcels of land to build a homestead, grow some staple crops, and build a kraal for small ruminants and dairy cattle (see Sanon et al. 2014). Considering that producers have different risk profiles and are generally risk-averse (Wiggins 2016), new breeding programs in the region should explicitly integrate risk management to increase the likelihood of participation.

\section{Livestock production system}

In earlier studies, production strategies and specific breeds were typically described in association with ethnic groups such as Lobi and Fulani (e.g., Mopaté et al. 2014; Soro et al. 2015; Dossa and Vanvanhossou 2016). We found, however, that the categorization based on ethnic groups has become less meaningful for tailoring interventions: the herd sizes of Lobi "sedentary crossbreed farms" were similar to those on Fulani "semi-transhumant Fulani zebu farms." Moreover, breed preferences have become less clear-cut: some sedentary farmers keep crossbred cattle for improved traction fitness and higher market value, and some semi-transhumant farmers recognized its superior resistance against diseases compared to pure Zebu cattle (see also: Mopaté et al. 2014; Sanon et al. 2014). In the literature, this dynamic is mainly attributed to a change in climate and increasing human migration: stocking herds as a savings strategy following favorable agricultural seasons has led to an increase in the number of zebu cattle in southwestern Burkina Faso (INSD 2014). Moreover, larger herds are more likely to be managed using transhumant strategies, as also found by Kaimba et al. (2011). Farmers with larger herds tend to employ herders, which may bring along cattle that are consequently crossbred with the herd owners' animals (Mopaté et al. 2014; Dossa and Vanvanhossou 2016). Finally, the fact that breeding was not considered a task to be managed in livestock production implies that interventions would first have to establish the benefits and costs of systematic breeding jointly with men, women and laborers.

\section{Constraints on cattle production}

Our study adds to the evidence that lack of drinking water for animals, the lack of feed (pasture), and the pressure of diseases and parasites are the primary challenges for livestock production in the region - as reported in previous studies (Soro et al. 2015; Koutou et al. 2017). Dossa and Vanvanhossou (2016) explained the decline of the Somba cattle population in Benin with the high mortality due to diseases, and feed and water shortage. According to Soudré et al. (2013) and Soro et al. (2015), trypanosomosis is a disease strongly reducing productivity in the region. Farmers, however, reported that over the past several years, the effect of foot and mouth disease has been even more adverse (Soudré et al. 2013). A likely contagion mechanism is transhumance during the dry season. In general, the identified constraints show the interlinkages of regional socio-ecological systems: the shortage of water has been explained by increased crop and cattle production in the region, as well as changing rainfall patterns. From 2006 to 2016, the farmed land in the 
region increased by $110 \%$ and cattle production increased by $31 \%$ (INSD 2016, 2018). The high international demand for cashew nut has contributed to the intensification of agriculture (Audouin 2014). Finally, the growing population in the region has further reduced the land available as pasture (Koutou et al. 2017). This shortage has likely increased conflicts between farmers and cattle keepers, who are competing for the same resources (Hellemans and Compere 1990; Vall et al. 2006; Gonin and Tallet 2012a, b.). Our conclusion is that breeding programs need to adopt a systemic perspective to integrate meaningfully with current trends in the agroecosystem.

\section{Methodology}

The results of this study should be interpreted taking into account the limitations of survey research. First, we must assume that the sample is not fully representative of the farmer population in the area. Second, the perspective of the household head may not fully reflect the realities experienced by other household members. Third, in standardized questioning, respondents make assumptions about the meaning of questions and potential answers (Strack and Schwarz 1992). These assumptions may lead to biases (e.g., social desirability).

We aimed to mitigate these limitations by (1), using a purposive sampling strategy to include the diversity of production systems, while not concluding on the quantitative ratio of the different types; by (2), complementing the household survey with FGDs to integrate the perspective of women and to validate the survey findings.

\section{Conclusion}

The purpose of this study was to understand cattle production systems in south-western Burkina Faso, given the importance of the sector for livelihoods and the endangerment of the local Lobi taurine breed. We identified four distinct types of production systems: (1) sedentary Lobi farms, (2) sedentary crossbreed farms, (3) semi-transhumant Fulani zebu farms, and (4) transhumant Fulani zebu farms. While Lobi taurine and crossbred animals continue to fulfill different livelihood and cultural roles, Lobi farmers have started to invest in cattle rearing as a complementary livelihood strategy. Fulani pastoralists have started to engage in crop production and continuous local marketing of animal products. Accordingly, traditional categories of "Lobi farmer" and "Fulani livestock keeper" do not fully reflect the reality of the sector-future preservation and breeding efforts must take this transition into account. Moreover, all identified production systems are increasingly confronting disease pressure and scarcity of water and land. Cattle breeding programs will need to respond to these trends in the agroecosystem, integrate risk management measures, and resonate with the specific needs of the different household members involved in cattle rearing.
Acknowledgments We are grateful to all farmers and livestock technicians for their active participation in the research activities.

Funding information Open access funding provided by University of Natural Resources and Life Sciences Vienna (BOKU). The research was funded by the Austrian Development Agency and the Austrian Partnership Programme in Higher Education and Research for Development (APPEAR 120).

\section{Compliance with ethical standards}

We obtained prior informed consent from all participants in the survey. To secure the confidentiality, accuracy, and security of the data, (1) only absolutely necessary data were collected (data minimization principle); (2) data were made available to the author team only after blinding (anonymization) by the team member collecting the data; (3) at no point were identifiable personal data published.

Conflict of interest The authors declare that they have no conflict of interest.

Open Access This article is licensed under a Creative Commons Attribution 4.0 International License, which permits use, sharing, adaptation, distribution and reproduction in any medium or format, as long as you give appropriate credit to the original author(s) and the source, provide a link to the Creative Commons licence, and indicate if changes were made. The images or other third party material in this article are included in the article's Creative Commons licence, unless indicated otherwise in a credit line to the material. If material is not included in the article's Creative Commons licence and your intended use is not permitted by statutory regulation or exceeds the permitted use, you will need to obtain permission directly from the copyright holder. To view a copy of this licence, visit http://creativecommons.org/licenses/by/4.0/.

\section{References}

Adeleye, O., Alli-Balogun, J.K., Afiemo, O.G., and Bako, S., 2016. Effects of goat production on the livestock of women in Igabi, Chikun and Kajuru Local Government Areas, Kaduna State, Nigeria, Asian Journal of Agricultural Extension, Economics and Sociology, 11, 1-8.

Altieri, M.A., Nicholls, C.I., Henao, A. and Lana, M.A., 2015. Agroecology and the design of climate change-resilient farming systems Agronomy for Sustainable Development, 35, 869-890.

ANAM, 2017. Rapport annuel des statistiques, (Agence National de la Météorologie/Direction Provincial de Gaoua, Burkina Faso).

Audouin, S., 2014. Systèmes d'innovation et territoires : un jeu d'interactions ; Les exemples de l'anacarde et du jatropha dans le sud-ouest du Burkina Faso, (PhD thesis, University of Paris I- Pantheon-Sorbonne).

Coulibaly, M., 1989. Systèmes d'élevage et productivité du cheptel bovin en pays Lobi (Burkina Faso), (Mémoire DESS. IEMVT, Maison Alfort), 85 p.

Dayo, G-K., 2009. Recherche de marqueurs génétiques associés à la tolérance et/ou sensibilité des bovins aux trypanosomes africaines, (Thèse Doctorat d'université, Université Montpellier II), 164p.

De la Rocque S., Michel J.F., D. Cuisance, G. De Wispelaere, P. Solano, X. Augusseau, M. Arnaud, S. Guillobez 2001. Du satellite au microsatellite. Le risque trypanosomien. Une approche globale pour une décision locale, (CIRAD, Montpellier), 151p.

Dossa, L.H., and Vanvanhossou, F.U.S., 2016. The indigenous Somba cattle of the hilly Atacora region in North-West Benin: threats and opportunities for its sustainable use, Tropical Animal Health and Production, 48, 349-359. 
Dossa L.H., Wollny C., Gauly M., Gbégo I., 2009. Community-based management of farm animal genetic resources in practice: framework for local goats in two rural communities in Southern Benin, Animal Genetic Resources, 44, 11-31.

Duguma G., Mirkena T., Haile A., Okeyo A.M., Tibbo M., Rischkowsky B., Sölkner J., Wurzinger M., 2011. Identification of smallholder farmers and pastoralists' preferences for sheep breeding traits: choice model approach, Animal, 5, 1984-1992.

FAO, 2010. Breeding Strategies for Sustainable Management of Animal Genetic Resources. FAO Animal Production and Health Guidelines, 3, (Food and Agriculture Organization of the United Nations, Rome).

FAO. 2015. The Second Report on the State of the World's Animal Genetic Resources for Food and Agriculture, (Food and Agriculture Organization of the United Nations, Rome, Italy)

FAO, 2018. L'impact des systemes de productions sur les moyens de subsistence au Burkina Faso. Filieres bovine et volaille. Elevage durable en afrique 2050. (Food and Agriculture Organization of the United Nations, Rome, Italy).

Gbegbelegbe, S., Serem, J., Stirling, C., Kyazze, F., Radeny, M., Misiko, M., Tongruksawattana, S., Nafula, L., Gakii, M. and Sonder, K., 2018. Smallholder farmers in eastern Africa and climate change: a review of risks and adaptation options with implications for future adaptation programmes, Climate and Development, 10, 289-306.

Gonin, A. and Tallet, B., 2012a. Changements spatiaux et pratiques pastorales: les nouvelles voies de la transhumance dans l'Ouest du Burkina Faso, Cahiers Agricultures, 21, 6, 448-454.

Gonin, A. and Tallet, B., 2012b. Quel avenir pour l'élevage dans le bassin cotonnier de l'Ouest du Burkina Faso? Dynamiques agro-pastorales et recompositions territoriales Autrepart, 60, 1, 95-110.

Haile, A., Mirkena, T., Duguma, G., Wurzinger, M., Rischkowsky, B., Tibbo, M., Okeyo, M. and Sölkner, J., 2013. Community based sheep breeding programs: Tapping into indigenous knowledge, Livestock Research for Rural Development, 25.

Hänke, H. and Barkmann, J., 2017. Insurance function of livestock, Farmers coping capacity with crop failure in southwestern Madagascar World Development, 96, 264-275.

Hellemans P., and Compere R., 1990. Aspects techniques et socioeconomiques de la transhumance des troupeaux de zebus en zone soudanienne de la Bougouriba (Burkina Faso), Tropicultura, 1990, $8,2,59-83$

INSD, 2014. Annuaire Statistique du Burkina Faso, (Institut National de la Statistique et de la Démographie, Burkina Faso).

INSD, 2016. Annuaire Statistique du Burkina Faso, (Institut National de la Statistique et de la Démographie, Burkina Faso).

INSD, 2018. Annuaire Statistique du Burkina Faso, (Institut National de la Statistique et de la Démographie, Burkina Faso).

Jahnke, H.E., 1982. Livestock production systems and livestock development in tropical Africa. (Kieler Wissenschaftsverlag Vauk, Germany), 241p.

Joliffe, I.T., 1986. Principal Component Analysis, (Springer-Verlag, Berlin).

Kaboré, M., 2012. Etude de la diversité génétique des taurins Baoulé du Burkina Faso a l'aide de marqueurs microsatellites, (DEA thesis, University of Ouagadougou).

Kaimba, G.K., Njehia, B.K., Guliye, A.Y., 2011. Effects of cattle rustling and household characteristics on migration decisions and herd size amongst pastoralists in Baringo District, Kenya, Pastoralism: Research, Policy and Practice, 1.

Koutou, M., Sangaré, M., Havard, M., Vall, E., Sanogo, L., Thombiano, T., Vodouhe D. S., 2017. Adaptation des pratiques d'élevage des producteurs de l'Ouest du Burkina Faso face aux contraintes foncieres et sanitaires, Agronomie Africaine, 28, 2, 1-87.

Kruska R.L., Reid R.S., Thornton P.K., Henninger N., Kristjanson P.M., 2003. Mapping livestock-oriented agricultural production systems for the developing world, Agricultural Systems, 77, 39-63.
MAHRH, 2011. Cadre d'action pour l'investissement agricole au Burkina Faso. (Ministère de l'Agriculture, de l'Hydraulique et des Ressources Halieutiques Burkina Faso, Ouagadougou), 88p.

MAHRH/GTZ, 2014. Mission d'appui à l'identification des interventions du Programme de Développement de l'Agriculture de la Coopération germano-burkinabé dans la région administrative du Sud-Ouest. Ouagadougou, (Ministère de l'Agriculture, de l'Hydrauliques et des Ressources Halieutiques Burkina Faso \& Deutsche Gesellschaft für Technische Zusammenarbeit).

MEF/DREP, 2014. Profil régional 2013 du Sud-Ouest, (Ministère de l'Economie et des Finances/Direction Régionale de l'Economie du Sud-Ouest, Burkina Faso).

Mirkena T., Duguma G., Willam A., Wurzinger M., Haile A., Rischkowsky B., Okeyo A.M., Tibbo M., Sölkner J., 2012. Community-based alternative breeding plans for indigenous sheep breeds in four agro-ecological zones of Ethiopia, Journal of Animal Breeding and Genetics, 129, 244-253

Mopaté, L.Y., Kamuanga, M.J-B., Hamadou, S., and Kaboré-Zoungrana, C-Y., 2014. Evaluation des pratiques paysannes de conservation in situ du taurin Baoulé au Sud-Ouest du Burkina Faso, Animal Genetic Resources, 54, 171-178.

Mueller J.P., 2013. Experiencias con estructuras genéticas para el mejoramiento de rumiantes menores en las zonas áridas. In: L.R. Iñiguez (eds.), La Producción de Rumiantes Menores en las Zonas Áridas de Latinoamérica, (EMBRAPA, Brasília), 497-513.

Nimbkar, C., Ghalsasi, P.M., Walkden-Brown, S.W., Kahn, L.P., 2002. Breeding program for the genetic improvement of Deccani sheep of Maharashtra, India: In: Proceedings of the 7th World Congress on Genetics Applied to Livestock Production, Montpellier/France, 2002.

Ojango J.M.K., Ahuya C., Okeyo A.M., Rege J.E.O., 2010. The FARMAfrica dairy goat improvement project in Kenya: a case study. In: J.M. Ojango, B. Malmfors, A.M. Okeyo (eds), Animal Genetics Training Resource, (International Livestock Research Institute, Nairobi, and Swedish University of Agricultural Sciences, Uppsala).

Ouédraogo, M., Dembélé, Y., Somé, L., 2010. Perceptions et strategies d'adaptation aux changements des preécipitations: cas des paysans du Burkina Faso, Sécheresse 21, 2, 87-96.

Robinson T.P., Wint G.W., Conchedda G., Van Boeckel T.P., Ercoli V., Palamara E., Cinardi G., D'Aietti L., Hay S.I., Gilbert M., 2014. Mapping the global distribution of livestock. PLoS ONE, 9, e96084.

Sanon, H. O., Savadogo, M., Tamboura, H. H. and Kanwé, B. A. 2014. Caractérisation des systèmes de production et des ressources fourragères dans un terroir test de la zone soudanienne du Burkina Faso, VertigO-La revue électronique en sciences de l'environnement, 14, 2.

Scherf, B., Tixier-Boichard, M., 2009. Production environment recording. Animal Genetic Resources, 44, 7-10.

Sicot, O., 1993. Importane socio-économique du cheptel bovin dans la province du poni (Burkina Faso), (Mémoire DESS. IEMVT, Maison Alfort), $59 \mathrm{p}$.

Sokouri D.P., Yapi-gnaore C V., N'Guetta A S P., Loukou N E., Kouao B J., Toure G., Sangare A et Kouassi A., 2009. Utilisation et gestion des races taurines locales sous la pression des croisements avec les zébus dans les régions Centre et Nord de la Côte d'Ivoire, Journal of Animal \& Plant Sciences. 5/2, 456-465.

Sölkner, J., Nakimbugwe, H. and Valle-Zárate, A., 1998. Analyses of determinants for success and failure of village breeding programmes. In: Proceedings of the Sixth World Congress on Genetics Applied to Livestock Production, Armidale/Australia, 1998.

Soro B., Sokouri, D.P., Dayo, G.K., N'Guetta A.S.P. and Yapi Gnaoré, C.V., 2015. Caractérisation des bovins de race Baoulé dans le "Pays Lobi" de Côte d'Ivoire: rôles socioéconomiques, modes d'élevage et contraintes de production, Tropicultura, 33, 2, 111-124.

Soudré A., Ouédraogo-Koné S., Wurzinger M., Müller S., Hanotte O., Ouédraogo A. G., Sölkner J., 2013. Trypanosomosis: a priority disease in tsetse-challenged areas of Burkina Faso, Tropical Animal Health and Production, 45, 3, 497-503. 
Sow, A., Sidibé I., Kamuaga, M., Maillard, J-C, Ly C., 2005. Epidémiologie et importance socio-économique de la dematophilose dans les élevages bovins du pay lobi (Sud-ouest du Burkina Faso), Revue Africaine de Santé et de Productions Animales, 3/1, 15-22.

Strack, F., and Schwarz, N., 1992. Communicative influences in standardized question situations: The case of implicit collaboration. In : K. Fiedler and G. Semin (eds), Language and social cognition, (Cambridge University Press : Cambridge).

Tano, K., Kamuanga, M.J.B., Faminow, M.D., Swallow, B.M. 2001. Adoption and demand for trypanotolerant cattle in the subhumide zone of West Africa, Journal of Agriculture and Environment for International Development 95(2-3), 213-235.

Tibshirani R, Walther G, Hastie T 2001. Estimating the number of clusters in a data set via the gap statistic. Journal of the Royal Statistical Society B, 63, 2, 411-423.

Vall, É., Dugué, P., Blanchard, M., 2006. Le tissage des relations agricultureélevage au fil du coton, 1990-2005, Cahiers Agriculture, 15, 1, 72-79.
Wiggins, S., 2016. Risk aversion among smallholder farmers in Uganda, (ODI: London).

Wurzinger, M., Sölkner, J. and Iniguez, L., 2011. Important aspects and limitations in considering community-based breeding programs for low-input smallholder livestock systems, Small Ruminant Research, 98:170-175.

Wurzinger, M., Escareno, L., Pastor, F., Salinas, H. and Sölkner, J., 2013. Design and implementation of a community-based breeding program for dairy goats in northern Mexico, Tropical and Subtropical Agroecosystems, 16, 2, 289-296.

Yapi-Gnoare, C.V., 2000. The open nucleus breeding programme of the Djallonké sheep in Côte D'Ivôire. In: Galal, S., Boyazoglu, J., Hammond, K. (eds.), Workshop on Developing Breeding Strategies for Lower Input Animal Production Environments, Bella/Italy, 1999.

Publisher's note Springer Nature remains neutral with regard to jurisdictional claims in published maps and institutional affiliations. 